\title{
マグネタイト微粒子の水相安定分散 一水ベース磁性流体の作成一
}

\author{
(1975 年 8 月 1 日受理)
}

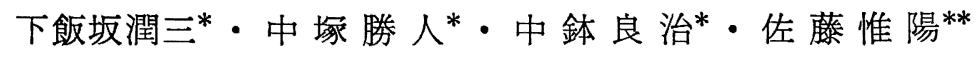

湿式法によるマグネタイトコロイドにオンイン酸イオンの単分子吸着を行なわせて表面疎水性とし, これにアニオン性あるいは非イオン性の界面活性剤を作用させ，水相で安定な分散液を得た。この 2 層 目の界面活性剂としては, ドデシルベンゼンスルホン酸ナトリウム, オレイン酸ナトリウムおよび HLB が 12 以上のポリオキシェチレンノニルフェニルェーテルが効果を示した。コロイド溶液の分散性の $\mathrm{pH}$ 变化は, 界面活性剂の解離特性により影響される。得られた分散液中のマグネタイトコロイドは, $5 \mathrm{kOe}$ 以下の磁場中では濃縮が認められず，いわゆる磁性流体とみなされる。一定磁場のもとでの磁性流体の 磁化は, 懸濁液のマグネタイト含有率に依存する。また, 磁性流体の磁化曲線はマグネタイトコロイド の超常磁性によって説明される。高い磁化值を与えるためマグネタイト含有率を高めた場合, 推定体積 分率約 40\% 付近から繊維状の凝集相が生じ，48\% で完全にゲル化することが認められた。

\section{1 緒言}

磁性流体 (magnetic fluid) ${ }^{1) ~ 3) ~}$ は, 強磁性微粉末を液相中に安 定に分散させたもので, 重力や通常の磁場のもとでは沈降や凝集 による固液分離が起こらず，液体が磁性をもっているようにふる まう性質を示す。その代表的なものは，既報のように無極性溶媒 中にオレイン酸で被覆したマグネタイトなどを分散させたもの で4)，磁性と流体挙動を利用した新しい応用が提案されているが， 用途によっては種々の溶媒が望まれることが多い。

本研究は, 水溶液中にマグネタイトュロイドを安定に分散させ て磁性流体を得る方法について検討したものである。磁性流体と してはその磁性が強く粘性が低い性質が望をれるため, 分散液は 高濃度低粘性であることが必要である。著者らは, 水溶液中でマ グネタイトコロイドの表面電位を高める方法によって分散化を試 みたが，この方法では濃密分散液の作成が困難で，かつ希薄分散 液でる磁場中に怙ける安定性飞難点があり磁性流体を得ることが できなかったので, 界面活性剤による二重被覆による分散化を検 討した。

\section{2 実験}

\section{1 試料の作成}

硫酸鉄 (II) と硫酸鉄 (III)の等モル混合液に水酸化ナトリウム溶 液を加え， $\mathrm{pH}$ を11としてマグネタイトコロイドを得た。この懸 濁液を洗浄して電解質を除いたのちオレイン酸ナトリウム溶液を

* 東北大学工学部資源工学科, 980 仙台市荒巻字青葉

** 東北金属工業株式会社, 982 仙台市郡山

1) R.E. Rosensweig, Encyclopaedic Dictionary of Physics Sppl., 4, 111(1971).

2) 可知祐次, 固体物理, 8, 449(1973).

3）下飯坂潤三, 中塚勝人, 表面, 13，103(1975).

4) 佐藤敏彦, 桶口重孝, 下飯坂潤三, 日本化学会第 19 年会講 演予稿集， I, p. 293(1966).
加え, $90^{\circ} \mathrm{C}$ に 30 分間たもって吸着反応を行なわせた。これを十 分洗浄して吸引沪過によって含水率約 $50 \mathrm{wt} \%$ のケーキとし， ついで第 2 層目の吸着層を得るための界面活性剤を加えてホモジ ナイザーによりかきまぜ, 試料分散液を得た。

\section{2 実験方法}

分散液の作成によって, 液中に安定に分散したマグネタイトの 全マグネタイト量に対する割合（マグネタイト分散率）をつぎの 方法により求めた。懸濁液のコロイド分散質含有量を $\theta(\mathrm{g} / \mathrm{m} l)$, 分散質の比重を $\rho_{\mathrm{C}}$, 水の比重を $\rho_{\mathrm{w}}$, 懸濁液の比重を $\rho$ とすれば, $\theta$ はを用いて次式で表わされる5)6)。

$$
\theta=\rho_{\mathrm{C}} \frac{\rho-\rho_{\mathrm{W}}}{\rho_{\mathrm{C}}-\rho_{\mathrm{W}}}
$$

したがって分散後の眯濁液の比重を $\rho_{1}$ とすれば，マグネタイト 分散率は次式から求められる。

$$
\text { 分散率 }=\frac{\rho_{1}-\rho_{\mathrm{w}}}{\rho-\rho_{\mathrm{W}}}
$$

分散率測定にさいしては，試料溶液を固体濃度が約 $20 \%$ となる よう調整し, $100 \mathrm{ml}$ 有せんメスシリンダーに採取して約 4 日間 静置後, 水面より約 $30 \mathrm{~mm}$ の深さの点から $10 \mathrm{ml}$ を分取してピ クノメーターでその比重を求め，(2)式により分散率を求めた。

分散液の粘性測定は室温 $\left(20^{\circ} \mathrm{C}\right)$ で Brookfield 型回転円筒粘度 計により，ぬた，磁化は室温で磁気テンビンにより求めた。ほか の実験法は結果の項でそのつど述べることとする。

\section{3 実験結果および考察}

無機粉末を水溶液に分散させるにさいして，粉末の水㲘濁液に

5) G. W. Reimers, S. E. Khalafalla, Bureau of Mines Innovative Process in Extractive Metallurgy Program Technical Report-59(1972).

6）下飯坂潤三，中塚勝人，中鉢良治，佐藤惟陽，粉体执よび 粉末冶金, 22，22(1975). 


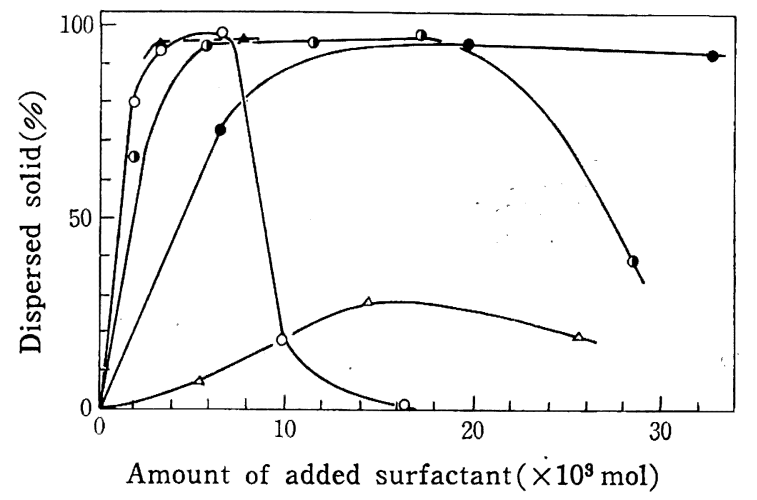

Fig. 1 Effect of surfactant on magnetite dispersion Solid content : $22 \mathrm{wt} \%$, Total suspension : $100 \mathrm{ml}$ 1 : SDBS, : Sodium oleate, $\triangle$ : POENPE(HLB 8), $\mathrm{O}: \mathrm{POENPE}$ (HLB 12), $\boldsymbol{\Delta}: \mathrm{POENPE}$ (HLB 18)

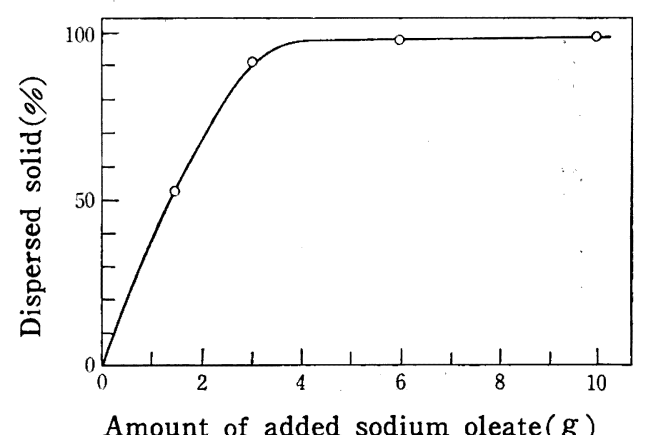

Fig. 2 Effect of sodium oleate on magnetite dispersion Magnetite content : $22 \mathrm{wt} \%$, Amount of added SDBS : $6 \mathrm{~g}$, Total suspension : $100 \mathrm{~m} l$

多量のイオン性界面活性剤を加える方法が効果的なことは古くか ら知られているところである。目黒らは，酸化鉄ゾルにドデシル 硫酸ナトリウムを加えて凝結させ，これに非イオン性界面活性剂

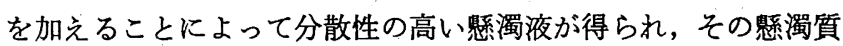
は電気泳動法で無電荷とみなされることがら，2 層目の非イオン 性界面活性剂の吸着層が分散に寄与していることを指摘してい る78)。また篠田らも, 別の目的から $\mathrm{AgBr}$ ゾルに対し同様の手 法を用いた例を報告している の反発が吸着膜の厚さ程度の短距離範囲で作用すると考えられる ので, 濃厚分散系を得るらえで優位性があると考えられる。

本研究に扣いては，オンイン酸イオンが既報10)のようにマグネ タイトに強い吸着性を示す点に注目し，2.1 で述べた方法により， あらかじめマグネタイトュロイドをオレイン酸ナトリウムで吸着 処理したのち、これに種々の界面活性剤を加えて分散夜を得る方 法について検討した。

図 1 はマグネタイト㣰濁夜に，マグネタイトに対して $30 \mathrm{wt} \%$ のオンイン酸ナトリウムを加えて吸着処理を行ない, 過劋の界面 活性剤と電解質を洗浄したのち沪過し，これにドデシルベンゼン スルホン酸ナトリウム (以下 SDBS と略記する), オレイン酸ナ

7）目黒謙次郎，近藤 保，日化，76，642(1955).

8）目黒謙次郎, 日化, 77, 77(1956).

9）国枝博信，篠田耕三，E. Matijevic，コロイド㧍よび界面 化学討論会要旨集, p. 107(1974).

10）下飯坂潤三，東北鉱山，6，99(1959).

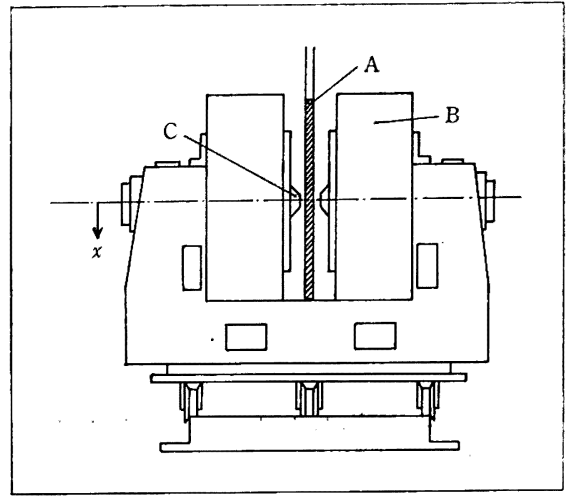

Fig. 3 Equipment for homogeneity test of magnetic fluid A : Magnetic fluid, B : Electro magnet, C : Pole piece

トリウム, あるいは HLB の異なる 3 種のポリオキシェチレンノ ニルフェニルェーテル（以下 POENPE と略記する）を加えて分 散させ, 固体濃度を約 $20 \mathrm{wt} \%$ に調整して, $100 \mathrm{ml}$ メスシリン ダー中に 100 時間静置したときのマグネタイト分散率を示したも のである。陰イオン性のオンイン酸ナトリウム, SDBS いずれに よっても安定な分散液が得られる。SDBS の場合の方が低濃度で 分散効果が得られ，一方また，オレイン酸ナトリウムと異なり， 多量の添加によって分散性が低下する傾向が認められる。

POENPE を用いた場合には，HLB 18 および 12 で高い分散性 が得られるが, HLB 8 では効果は認められない。HLB 12 の POENPE によって高い分散性の得られる添加量の範囲は狭い。 HLB 18 の POENPE では, その添加にともなら粘性の増加がは げしいために， $10 \times 10^{-8} \mathrm{~mol}$ 以上では分散率の湘定が不可能であ った。なお，陽イオン性のドデシルアンモニウムアセタートでは 良好な分散は得られなかった。

L․ 図 1 で得られる分散液の $\mathrm{pH}$ 変化に対する安定性は第 2 層目の 界面活性剤の種類によって異なる。オレイン酸ナトリウム, SDBS および HLB12 のポリオキシェチレンノニルフェニルェーテルを 用いた分散液の分散性の良好な $\mathrm{pH}$ 範囲はおのおの, $\mathrm{pH} 8$ 8 12 , 3〜12，2〜14 である。これから分散性を与える低 $\mathrm{pH}$ 側の限界 は，陰イオン界面活性剂ではその解離度により，また非イオン界 面活性剂ではマグネタイトの酸溶解によって決められていると思 われる。また高 $\mathrm{pH}$ 側での分散性の劣化は明瞭ではないが, 陰イ オン性界面活性剤の場合粘性がいちじるしく増大する。これは界 面活性剤のアルカ、塩の析出が括もな原因と考えられる。

図 2 は, 第 2 層目の界面活性剂として SDBS を用いた場合に ついて, 第 1 層目のオレイン酸イオンの被覆量がマグネタイト分 散率に与える影響を調べた結果である。同法で作成した界面活性 剂未処理のマグネタイトの BET 比表面積は $120 \mathrm{~m}^{2} / \mathrm{g}$ (球相当径 $100 \AA ̊$ ）であった。この值とオレイン酸イオンの吸着分子断面積 $30 \AA^{2}$ 10) 中約 $3 \mathrm{~g}$ に相当している。オレイン酸イオンはマグネタイトに吸 着しやすく，その平衡濃度は単分子吸着の完成まではきわめて低 いといら特徵をあわせ考光ると, 図 2 において高い分散性を得る ためには, 表面第 1 層目はほぼ単分子状に被覆されていることが 必要と推定される。なお，このマグネタイトの平均粒径は電子顕 微鏡によって約 $90 \AA$ と求められた。 


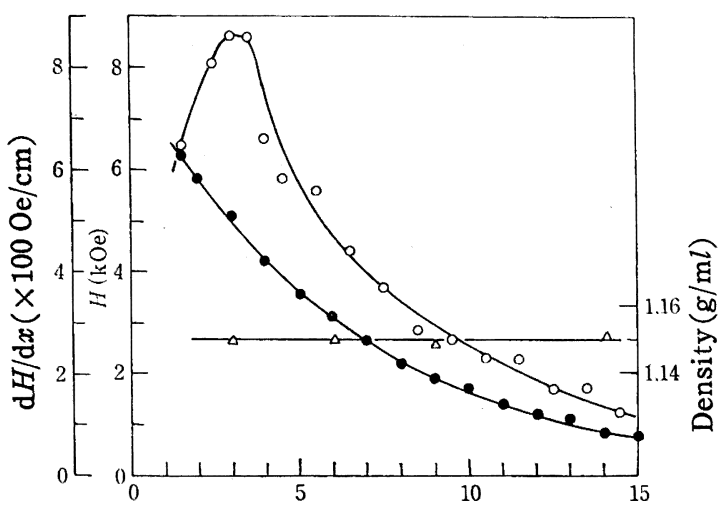

Distance from center of magnet pole piece $(\mathrm{cm})$

Fig. 4 Homogeneity of the fluid in magnetic field : $H, \bigcirc: \mathrm{d} H / \mathrm{d} x, \triangle:$ Density

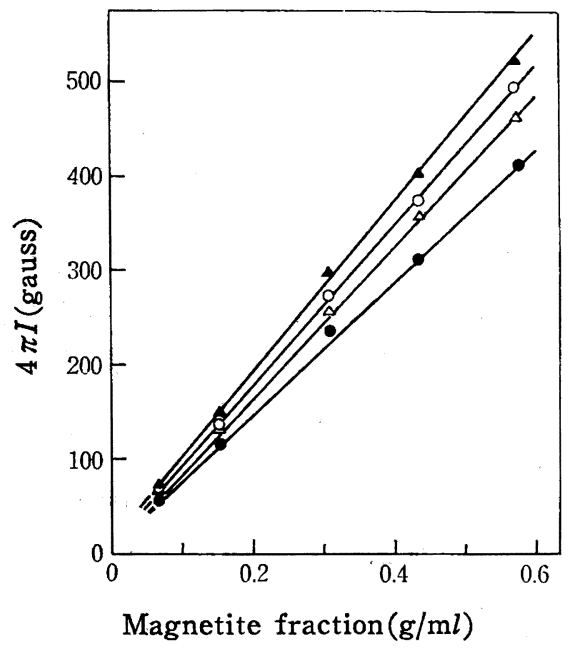

Fig. 5 Relation between magnetization of fluids and magnetite fraction

Applied magnetic field(Oe) -
$\Delta: 8800, \bigcirc: 6000, \triangle: 4000$, $: 2000$

\section{3 磁性流体としての二三の性質}

分散夜を磁性流体として用いるためとは，磁場を印加しても分 散質の凝結や濃度偏析が起こらないことが必要である。ここに, 前者は分散質間の磁気的な吸引力が増すことにより，また後者は 分散質あるいはその凝結体が磁場より受ける力 $F=v \cdot I \cdot \partial H / \partial x$ により高磁場側に移動することにより起こる現象をさしている。 ただし，vは分散質（あるいは凝結体）の体積，Iはその磁化， $\partial H / \partial x$ 滋場勾配である。この検討のために図 3 の上らに, 電 磁石の磁極の中心に立てた内径 $30 \mathrm{~mm}$ のガラス管に分散液を满 たし，中心磁場 $8 \mathrm{kOe}$ を印加して 3.5 時間静置後各深さの点から 分散液 $5 \mathrm{~m} l$ を採取し比重を測定した。分散夜はマグネタイト $100 \mathrm{~g}$ 飞対してオレイン酸ナトリウムを $34 \mathrm{~g}$, SDBS を $22 \mathrm{~g}$ の割合で用い，全量を $500 \mathrm{ml}$ として得たものである。因 4 に採 取点に打浽磁場，磁場勾配と採取液の比重を示した。 $5 \mathrm{kOe}$ 以

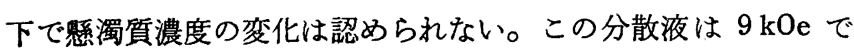
磁化 $11 \mathrm{emu} / \mathrm{g}$ を示するのである。

図5は，オレイン酸ナトリウムとSDBS を用いて得たマグネ タイトコロイドの分散液について, 磁化とマグネタイト濃度の関 係を示したものである。図中横軸の值は，分散液の鉄の化学分析

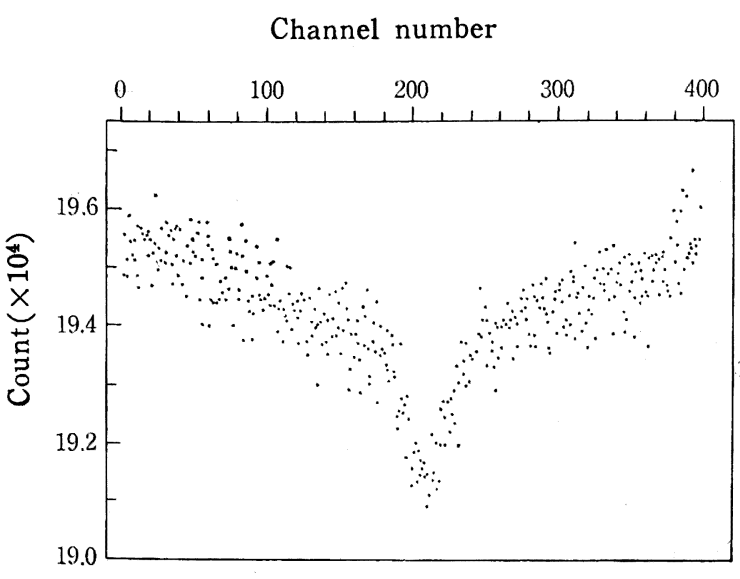

Fig. 6 Mössbauer spectrum of magnetite by wet method

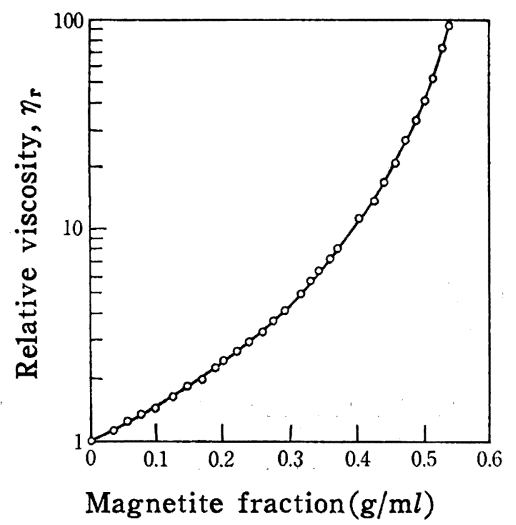

Fig. 7 Relation between viscosity and magnetite fraction of fluids

品位から $\mathrm{Fe}_{3} \mathrm{O}_{4}$ 飞換算して求めた。分散液の磁化は，磁場一定 のもとではマグネタイト含量に比例するが，高い磁場においても 飽和せず磁場の増加にともない漸增する。図の直線勾配から， 、 グネタイトの磁化は $8.8 \mathrm{kOe}$ とおいて $4 \pi I て ゙ ~ 930$ gauss $/ \mathrm{g}, 74$ $\mathrm{emu} / \mathrm{g}$ と求められるが, これは天然のマグネタイトの值 $95 \mathrm{emu} /$ $\mathrm{g}$ の約 78\% にすぎない。この理由としてはマグネタイトがきわ めて微細であることが考兄られる。図6にこの分散コロイドの Mössbauer スペクトルを示す。中央の常磁性による吸収が強く， 強磁性による吸収はほとんと認められないことから，コロイドの 大部分は超常磁性粒子と考兄られ，このために磁化の磁場依存性 や磁化の不足が生じるものと考觉られる。

磁性流体の磁化を大きくするためにはマグネタイト含有量を増 すことになるが，これには当然粘性の增加がともなら。図7はマ グネタイト含有量が粘性に与える影響を調べた結果である。この 溶液を 100 あるいは 500 倍の顕微鏡下で観察した結果, 図 7 亿示 したマグネタイト濃度約 $0.55 \mathrm{~g} / \mathrm{m} l$ 以下ではコロイドは完全に 分散しているが, $0.6 \mathrm{~g} / \mathrm{m} l$ では繊維状の析出物が混じ, マグネ タイト濃度とともにこれが增加することが認められ，約 $0.7 \mathrm{~g} / \mathrm{m} l$ でほぼ完全にゲル化した。

図 7 亿䄧いてコロイドの粒径を一定と考光，マグネタイトの低 濃度域 $(<0.1 \mathrm{~g} / \mathrm{m} l)$ の粘性変化飞 Einstein の式, $\eta_{\mathrm{r}}=1+2.5$ $\phi(\phi$ : 体積分率 $)$ を適用して求めた水力学的体積からは, 球相 当径として $200 \AA$ の值が得られる。

一方, マグネタイト含量 $0.464 \mathrm{~g} / \mathrm{m} l$ の分散液 $(\rho=1.35) 20 \mathrm{~m} l$ 
の乾燥後の重量は $13.25 \mathrm{~g}$ であった。これから乾燥産物の密度 として $2.12 \mathrm{~g} / \mathrm{m} l$ が得られる。マグネタイトの密度を 5.0 , 界 面活性剤のそれをオレイン酸と同じ 0.9 とし, 球状のマグネタイ トを界面活性剤が被覆していると仮定すると ${ }^{11)}$, 上記の值から被 覆膜の厚さは粒半径の $1 / 2$ ，すなわらマグネタイトコロイドの粒 径を $100 \AA$ とすれば被覆粒子径は $150 \AA$ 程度と見積られる。こ の値を用いると図 7 においてマグネタイト含有量 $0.6 \mathrm{~g} / \mathrm{ml}$ は被 覆コロイドの体積分率で約 $40 \%$ に相当し，ゲル化する $0.7 \mathrm{~g} / \mathrm{ml}$ では $48 \%$ で最蹯充テンに括ける值 $52 \%$ にほぼ近いと推定され る。

11）実際には分散液中には吸着イオンと平衡しているSDBSが ある。

\section{4 結 論}

湿式法によるマグネタイトコロイドにオレイン酸イオンの単分 子吸着を行なわせ，これに別種の界面活性剤を作用させて安定な 分散液を得た。第 2 層目の吸着層を得るための界面活性㶡として は，陰イオン性の SDBS，オレイン酸ナトリウム，非イオン性の HLB が 12 以上のポリオキシェチレンノニルフェニルェーテルが 効果を示した。得られた分散液中のマグネタイトコロイドは 5 $\mathrm{kOe}$ 以下の磁場中で濃縮を起こさない。その磁化は通常のマク ネタイトにくらべ飽和し難いが，これはマグネタイトコロイドが 超常磁性を示すことによると解釈した。分散液中のコロイド含有 量を増加させた場合; 推定体積分率約 40\% 付近から瀻維状の凝 集相を生じ，48\% でほぼ完全にゲル化することが認められた。 (1975 年 4 月, 日本化学会第 32 春季年会発表)

\author{
Stabilization of Aqueous Magnetite Suspension \\ -Preparation of Water-Base Magnetic Fluid-_ \\ Junzo Shimorizaka, Katsuto Nakatsuka \\ Ryoji Chubachi and Yoshiharu Sato \\ Department of Mining and Mineral Engineering \\ Faculty of Technology, Tohoku University ; \\ Aoba, Aramaki, Sendai-shi 980 Japan
}

The stable aqueous suspensions of magentite colloid were obtained by allowing anionic or nonionic surfactant to adsorb on the hydrophobic surface of colloidal magnetite prepared by monomolecular adsorption of oleate.

It was found that sodium dodecylbenzenesulfonate, sodium oleate and poly(oxyethylene) nonyl phenyl ethers, whose HLB values being higher than 12 , are suitable for giving a double adsorption layer to attain a stable dispersion.

The change in the stability of colloidal suspension with $\mathrm{pH}$ of the solution relates to the dissociation of surfactant of outer layer. Under the applied field of $5 \mathrm{kOe}$, the enrichment of concentration of dispersed magnetite colloid was not observed in this suspension and the suspension could be regared as a magnetic fluid. The magnetization in a constant magnetic field parallels the magnetite content of the suspension. The dependence of magnetization of the fluid on magnetic field was explained in terms of super-paramagnetism of the magnetite colloid. When colloid content of the fluid is increased to obtain a large magnetization, the fiber-like coagulated phase is partially formed in the suspension whose colloid content being more than $40 \mathrm{vol} \%$. Finally, the suspension, whose colloid content being above $48 \mathrm{vol} \%$, changes into gel-like aggregate. 